\title{
Dynamics of Ions in Soils Irrigated with Saline Reject
}

\author{
Andler Milton Paiva de Oliveira ${ }^{1}$, Cezar Augusto Medeiros Rebouças ${ }^{1}$, Nildo da Silva Dias ${ }^{1}$, \\ Francisco Souto de Sousa Júnior ${ }^{2}$, Francisco Vanies da Silva Sá ${ }^{3}$, Osvaldo Nogueira de Sousa Neto², \\ Alexandre de Oliveira Lima ${ }^{1} \&$ Cleyton dos Santos Fernandes ${ }^{1}$ \\ ${ }^{1}$ Department of Environmental Sciences and Technological, Federal Rural University of the Semi-Arid, \\ Mossoró, RN, Brazil \\ ${ }^{2}$ Department of Exact, Technological and Human Sciences, Federal Rural University of the Semi-Arid, Angicos, \\ RN, Brazil \\ ${ }^{3}$ Academic Unit of Agricultural Engineering, Federal University of Campina Grande, Campina Grande, PB, \\ Brazil \\ Correspondence: Francisco V. da S. Sá, Academic Unit of Agricultural Engineering, Federal University of \\ Campina Grande, Paraíba, Brazil. Tel: 55-083-99861-9267. E-mail: vanies_agronomia@hotmail.com
}

Received: August 24, 2017

Accepted: September 20, 2017

Online Published: October 15, 2017

doi:10.5539/jas.v9n11p190

URL: https://doi.org/10.5539/jas.v9n11p190

\begin{abstract}
The objective of this work was to evaluate the variation in the electrical conductivity and the mobilization of ions present in reject brine from desalination plant of brackish well water in three types of soil. The mobilization of the contaminant ions in the reject brine was studied in glass percolation columns, which were filled with soil of contrasting textures (eutrophic CAMBISOL, typic dystrophic Red OXISOL, ENTISOL Quartzipsamment). Experiments ware repeated three times each, and the initial and final concentrations of the ion contaminants were analyzed. The pollution potential of this residue was determined by the retardation factor and dispersion-diffusion coefficient of $\mathrm{Ca}^{2+}$ and $\mathrm{Mg}^{2+}$, besides the variation of electrical conductivity along the profile of each soil studied. In the Red Oxisol, $\mathrm{Ca}^{2+}$ and $\mathrm{Mg}^{2+}$ ions move with greater ease resulting in possibility largest of potential of ground water contamination. In Entisol Quartzipsamment presented higher $\mathrm{Mg}^{2+}(\mathrm{R})$ ion advancement speed, that is, higher subsurface contamination power for these ions. The eutrophic Cambisol presented low diffusion-dispersion coefficient in all the evaluated ions and, therefore, lower mobility of the ions in the soil profile, and consequently, a greater possibility of contamination when irrigated with reject brine.
\end{abstract}

Keywords: irrigation, semi-arid, water reuse, reverse osmosis, calcium, magnesium

\section{Introduction}

The rational use of water in irrigated agriculture has been a recurrent discussion along the last decades, especially with respect to water quality (Ayers \& Westcot, 1999; Silva et al., 2007; Anami et al., 2008). The use of water with high contents of salts results in the salinization of agricultural soils, causing disorders of physical and chemical nature in these soils, besides limiting crop development (Miranda et al., 2011; Mesquita et al., 2015; Sá et al., 2015). Since the water in some wells has high content of salts, desalinators have become necessary to make its use viable, and reverse osmosis desalination is one of the most employed techniques in arid and semi-arid regions (Santos et al., 2010a; Cosme et al., 2011; Oliveira et al., 2016).

Brackish water desalination through reverse osmosis allows the use of water for human consumption and agriculture. However, besides purified water, this process generates saline waste with high potential of soil salinization, which requires adequate disposal (Santos et al., 2011). In general, the final disposal of the saline waste in the soil results in its salinization, thus compromising its chemical and physical quality. In this context, this waste poorly managed in agriculture may pose risks to the environment, promoting soil salinization and reduction of agricultural production (Garcia et al., 2008; Dias et al., 2010; Santos et al., 2011).

The percolation column is a tool used to simulate the behavior of solute movement through the soil. It is based on the principle of accommodation of previously treated soil with well-known physical characteristics, followed by the application of the solution to be studied in the soil, with subsequent infiltration, and the collection of the predetermined pore volumes. Importantly, the dimensions of the column are measured in order to calculate the pore volume to be collected (Silva et al., 2012; Matos et al., 2013; Pinho et al., 2014; Silva et al., 2016). 
Given the above, the study on the dynamics of ions present in the saline wastewater disposed in the soil is of extreme importance for the evaluation of the contamination potential, either of soil and/or water sources; in addition, the ions present in this water will show different behaviors for each type of soil (Oliveira et al., 2016).

Therefore, the present study aimed to evaluate the variation in electrical conductivity and mobilization of calcium $(\mathrm{Ca})$ and magnesium $(\mathrm{Mg})$ ions present in saline wastes from the brackish water desalination process in three types of soil, in order to contribute with information on the polluting potential of these waters.

\section{Material and Methods}

The experiment was carried out at the Soil Physics Laboratory from Rural Federal University of Semi-Árido (UFERSA). Three soil types of Caatinga bioma from different regions of Baraúna and Natal, Rio Grande do Norte State, were used. The classification of the soils and their locations are shown in Table 1.

Table 1. Studied soil classifications and taken locations of sample

\begin{tabular}{ll}
\hline Classification (SiBCS) & Location (RN) \\
\hline Eutrophic CAMBISOL & Baraúna \\
Typic Dystrophic Red OXISOL & Alagoinha, Mossoró \\
Entisol Quartzipsamment & Boa Fé, Mossoró \\
\hline
\end{tabular}

Note. SiBCS: Brazilian Soil Classification System.

Each percolation column was filled with one type of soil sample, and the experiment was performed in triplicate, producing a total of nine experimental units. The soil was filled to a height of $0.20 \mathrm{~m}$ within the percolation column, with a crushed stone layer of $0.005 \mathrm{~m}(1.00$ to $0.50 \mathrm{~mm})$ as a base to facilitate drainage and to prevent loss of soil material (Figure 1).

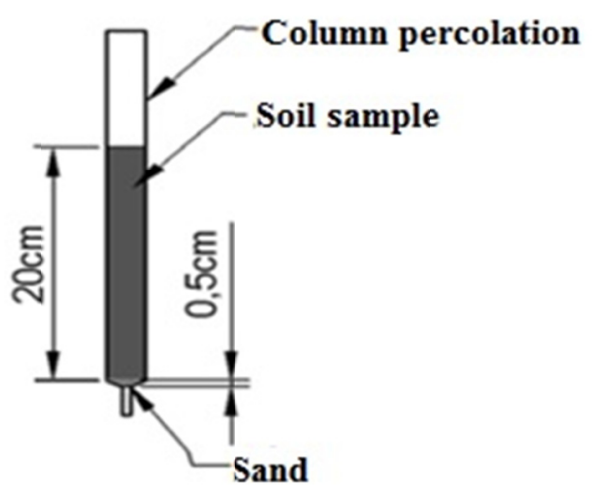

Figure 1. Schematic drawing for assembling and filling the percolation columns soil micro arthropods collecting was made with an Uhland-type. Soils were taken from the top $20 \mathrm{~cm}$ deep layer in a zigzag pattern for the percolation study to ensure that representative samples were obtained from each site. Soil samples with deformed structures were taken for analyses of the chemical and physical parameters. To perform the analyses, samples were used as air-dried fine earth (ADFE), obtained by air-drying, crumbling and sieving $(<2 \mathrm{~mm})$. To perform soil bulk density and total porosity, collecting of soil samples of un-deformed structures were made with

Uhland-type, stainless steel auger $5 \mathrm{~cm}$ in diameter and $5 \mathrm{~cm}$ in height. The physical and chemical analyses followed the recommendations outlined in the Manual of Soil Analysis Methods (Embrapa, 1997)

The assessment physical parameters included: particle size distribution by pipette method utilizing sodium hexametaphosphate as a chemical dispersant; solid density $\left(\rho_{\mathrm{s}}\right)$ by the volumetric flask method; soil density $(\rho)$ by volumetric ring method and, total porosity $(\alpha)$ as described in Equation 1.

$$
\alpha=\left(1-\frac{\rho}{\rho_{\mathrm{s}}}\right) \times 100
$$

Where, $\alpha$ is the total calculated porosity (\%), $\rho$ is the soil density, $\left(\mathrm{kg} \mathrm{dm}^{-3}\right)$, and $\rho_{\mathrm{s}}$ is the solid density $\left(\mathrm{kg} \mathrm{dm}^{-3}\right)$. Results are shown in Table 2. 
Table 2. Distribution of particle size, texture classification, soil density $(\rho)$, solid density $\left(\rho_{\mathrm{s}}\right)$, and calculated total porosity $(\alpha)$

\begin{tabular}{|c|c|c|c|c|c|c|c|}
\hline \multirow{2}{*}{ Soil } & \multicolumn{3}{|c|}{ Particle size distribution } & \multirow{2}{*}{$\begin{array}{l}\text { Texture classification } \\
\text { (SBCS) }\end{array}$} & \multirow{2}{*}{$\mathrm{P}$} & \multirow[b]{2}{*}{$\rho_{\mathrm{s}}$} & \multirow{2}{*}{$\alpha$} \\
\hline & Sand & Silt & Clay & & & & \\
\hline & \multicolumn{3}{|c|}{------------ $\left(\mathrm{g} \mathrm{kg}^{-1}\right)$-------- } & & \multicolumn{2}{|c|}{---- $\left(\mathrm{kg} \mathrm{dm}^{-3}\right)$---- } & $(\%)$ \\
\hline Eutrophic Cambisol & 662.80 & 96.50 & 240.70 & Frank-clay-sandy & 1.46 & 2.47 & 40.89 \\
\hline typic dystrophic Red Oxisol & 823.80 & 28.40 & 147.80 & Sand-frank & 1.68 & 2.51 & 33.07 \\
\hline Entisol Quartzipsamment & 897.50 & 21.60 & 80.90 & Sand & 1.64 & 2.59 & 36.68 \\
\hline
\end{tabular}

Note. SBCS: Brazilian Society for Soil Science; $\rho$ : soil density; $\rho_{\mathrm{s}}$ : solid density; $\alpha$ : calculated total porosity.

Measured chemical characteristics were: Soil $\mathrm{pH}\left(\mathrm{H}_{2} \mathrm{O}\right)$ determined in a solution of 1:2.5 soil-water mixture, electrical conductivity of the saturated soil-paste extract $\left(\mathrm{EC}_{\mathrm{s}}\right)$, exchangeable calcium $\left(\mathrm{Ca}^{2+}\right)$ and magnesium $\left(\mathrm{Mg}^{2+}\right)$ by by complexometry after extraction with $\mathrm{KCl} 1 \mathrm{~mol} \mathrm{~L}^{-1}$, exchangeable aluminum $\left(\mathrm{Al}^{3+}\right)$ by extraction with $\mathrm{KCl} 1 \mathrm{~mol} \mathrm{~L}^{-1}$ and titrated with $\mathrm{NaOH} 0.025 \mathrm{~mol} \mathrm{~L}^{-1}$, available phosphorus $(\mathrm{P})$, sodium $\left(\mathrm{Na}^{+}\right)$and potassium $\left(\mathrm{K}^{+}\right)$extracted in Mehlich-1 and determined by spectrophotometry visualization $(\mathrm{P})$ and detected by flame photometry $\left(\mathrm{Na}^{+}\right.$and $\left.\mathrm{K}^{+}\right)$, the potential acidity $(\mathrm{H}+\mathrm{Al})$ - quantified by titration with $0.025 \mathrm{~mol} \mathrm{~L}^{-1} \mathrm{NaOH}$ after extraction with calcium acetate at a concentration of $0.5 \mathrm{~mol} \mathrm{~L}^{-1}$ with a $\mathrm{pH}$ of 7.0 and, soil organic matter (SOM) - as assessed by $0.005 \mathrm{~mol} \mathrm{~L}^{-1}$ ferrous ammonium sulfate titration after being heated in a uniform plate with $0.02 \mathrm{~mol} \mathrm{~L}^{-1}$ potassium dichromate (Table 3).

Table 3. Characterization of soil chemical properties

\begin{tabular}{|c|c|c|c|c|c|c|c|c|c|c|}
\hline Soil & $\mathrm{pH}$ & $\mathrm{EC}_{\mathrm{s}}$ & SOM & $\mathrm{P}$ & $\mathrm{K}^{+}$ & $\mathrm{Na}^{+}$ & $\mathrm{Ca}^{2+}$ & $\mathrm{Mg}^{2+}$ & $\mathrm{Al}^{3+}$ & $(\mathrm{H}+\mathrm{Al})$ \\
\hline & (water) & $\left(\mathrm{dS} \mathrm{m}^{-1}\right)$ & $\left(\mathrm{g} \mathrm{kg}^{-1}\right)$ & \multicolumn{3}{|c|}{--------- $\left(\mathrm{mg} \mathrm{dm}^{-3}\right)$--------- } & \multicolumn{4}{|c|}{-------- $\left(\mathrm{cmol}_{\mathrm{c}} \mathrm{dm}^{-3}\right)$--------- } \\
\hline 1 & 7.46 & 0.06 & 10.99 & 2.28 & 166.87 & 21.74 & 6.24 & 2.50 & 0.00 & 8.58 \\
\hline 2 & 5.35 & 0.06 & 8.80 & 1.41 & 35.29 & 15.96 & 0.98 & 0.49 & 0.06 & 3.82 \\
\hline 3 & 6.00 & 0.06 & 6.51 & 9.10 & 55.24 & 17.66 & 1.55 & 1.17 & 0.02 & 0.33 \\
\hline
\end{tabular}

Note. $\mathrm{pH}$ - hydrogen potential, $\mathrm{EC}_{\mathrm{s}}$ - electrical conductivity of the saturated soil-paste extract, $\mathrm{SOM}$ - soil organic matter, $\mathrm{P}$ - available phosphorus, $\mathrm{K}^{+}$- potassium, $\mathrm{Na}^{+}$- sodium, $\mathrm{Ca}^{2+}$ - calcium, $\mathrm{Mg}^{2+}$ - magnesium, $\mathrm{Al}^{3+}$ - aluminum and, $(\mathrm{H}+\mathrm{Al})$ - potential acidity. Soil 1 = Eutrophic Cambisol; Soil 2 = typic dystrophic Red Oxisol; Soil 3 = Entisol Quartzipsamment.

The reject brine sampling was taken in the Boa Fé rural community in Mossoró, Rio Grande do Norte State, Brazil. This community has a desalination plant by reverse osmosis that provides treated water to the population and, as a result of the desalination process, also generates reject brine.

The chemical characteristics of the saline tailings measured in this study were $\mathrm{pH}$, electric conductivity $\left(\mathrm{EC}_{\mathrm{w}}\right)$, potassium $\left(\mathrm{K}^{+}\right)$, sodium $\left(\mathrm{Na}^{+}\right)$, calcium $\left(\mathrm{Ca}^{2+}\right)$, magnesium $\left(\mathrm{Mg}^{2+}\right)$, chloride $\left(\mathrm{Cl}^{-}\right)$, and the sodium adsorption ratio (SAR), which was determined according to the methodology described by Tedesco et al. (1995) (Table 4).

Table 4. Reject brine chemical analysis

\begin{tabular}{|c|c|c|c|c|c|c|c|}
\hline $\mathrm{pH}$ & $\mathrm{EC}_{\mathrm{w}}$ & $\mathrm{K}^{+}$ & $\mathrm{Na}^{+}$ & $\mathrm{Ca}^{2+}$ & $\mathrm{Mg}^{2+}$ & $\mathrm{Cl}^{-}$ & SAR \\
\hline & & \multicolumn{2}{|c|}{ - } & \multicolumn{2}{|c|}{----- $\left(\mathrm{mmol}_{\mathrm{c}} \mathrm{L}^{-1}\right)$------ } & \multicolumn{2}{|c|}{--- $\left(\mathrm{mmol}_{\mathrm{c}} \mathrm{L}^{-1}\right)^{1 / 2}$} \\
\hline 7.42 & 10.15 & 0.80 & 4.11 & 31.49 & 25.21 & 89.70 & 0.76 \\
\hline
\end{tabular}

Note. $\mathrm{pH}$ - hydrogen potential; $\mathrm{EC}_{\mathrm{w}}$ - electrical conductivity; $\mathrm{K}^{+}$- potassium; $\mathrm{Na}^{+}$- sodium; $\mathrm{Ca}^{2+}$ - calcium; $\mathrm{Mg}^{2+}$ - magnesium; $\mathrm{Cl}^{-}$- chloride; SAR - sodium adsorption ratio.

According to the $\mathrm{EC}_{\mathrm{w}}$ data, the water is highly brackish $\left(\mathrm{EC}_{\mathrm{w}}=10.15 \mathrm{dS} \mathrm{m}{ }^{-1}\right)$, and it appears, according to the guidelines proposed by Ayers and Westcot (1999), that the reject brine have a severe use restrictions due to salinity risks $\left(\mathrm{EC}_{\mathrm{w}}>3.00 \mathrm{dS} \mathrm{\textrm {m } ^ { - 1 }}\right)$. Additionally, according to the same authors, the chloride ion has a severe degree of restriction $\left(\mathrm{Cl}^{-}>10 \mathrm{mmol}_{\mathrm{c}} \mathrm{L}^{-1}\right)$. 
To fill the percolation columns, volume was calculated using the dimensions of $390 \mathrm{~mm}$ height and $34.52 \mathrm{~mm}$ diameter. The soil was weighed to determine a bulk density measure and for total porosity calculations. Before filling the soil, the gravel layer was moistened to facilitate packing of the soil, thus reducing the chance of the soil passing the gravel. The determination of soil volume, pore volume, soil saturation and percolate collection are described in Oliveira et al. (2016).

Each solution sample was placed on properly identified collectors with each soil, repetition, and pore volume to be collected. All collectors were closed and sealed with adhesive tape to prevent possible loss. Then, the samples were allocated and stored in a freezer at an optimum temperature to avoid evaporative loss.

After reaching a permanent outflow in the percolation column, a five-pore volume pulse of displacing solution was applied, collecting effluent fractions with a 0.5 -pore volume, which were placed in plastic containers with pressurized covers and frozen for further analysis. The $\mathrm{K}, \mathrm{Na}$ and $\mathrm{Cl}$ concentrations in the effluent were determined $(\mathrm{C})$. The relative concentrations $\left(\mathrm{C} / \mathrm{C}_{0}\right)$ for each ion were calculated, $\mathrm{C}_{0}$ being the concentration in the shifter fluid.

The retardation factor $(\mathrm{R})$ and the dispersion-diffusion coefficient $(\mathrm{D})$ values were obtained from the DISP program (Borges Júnior \& Ferreira, 2006). As input data for the program, the following variables were used: flow, total porosity, soil column height $(20 \mathrm{~cm})$, pore volume, and experimental relative concentration.

The output variables were the $\mathrm{R}$ and $\mathrm{D}$ values, which were analyzed by the Tukey test at a $5 \%$ probability $(\mathrm{P}<$ $0.05)$. The Tukey test with a $5 \%$ probability was used to analyze the experimental data using SISVAR software (Ferreira, 2011).

\section{Results and Discussion}

$\mathrm{The} \mathrm{Ca}^{2+}$ ion exhibited a sigmoid behavior in all soils studied, evidencing the adsorptive effect of these soils with $\mathrm{Ca}^{2+}$, allowing to obtain its respective transport parameters under conditions of soil contamination by the excess of salts from the waste of desalinators (Figure 2). For the studied soils, the Latosol and Neosol reach their maximum levels of relative correlation with only $0.6 \mathrm{NPV}$, which is related to the predominance of macropores, directly responsible for water conduction in the soil during infiltration processes (Silva et al., 2012; Pinho et al., 2014; Silva et al., 2016). In addition, the Cambisol had the highest peak of the $\mathrm{Ca}^{2+}$ ion compared with the other soils, even exceeding $1 \mathrm{C} / \mathrm{Co}$ (Figure 2). This fact can be related to the large presence of calcium carbonate in these soils (Santos et al., 2013), which, after being solubilized, was leached along with the wastewater.

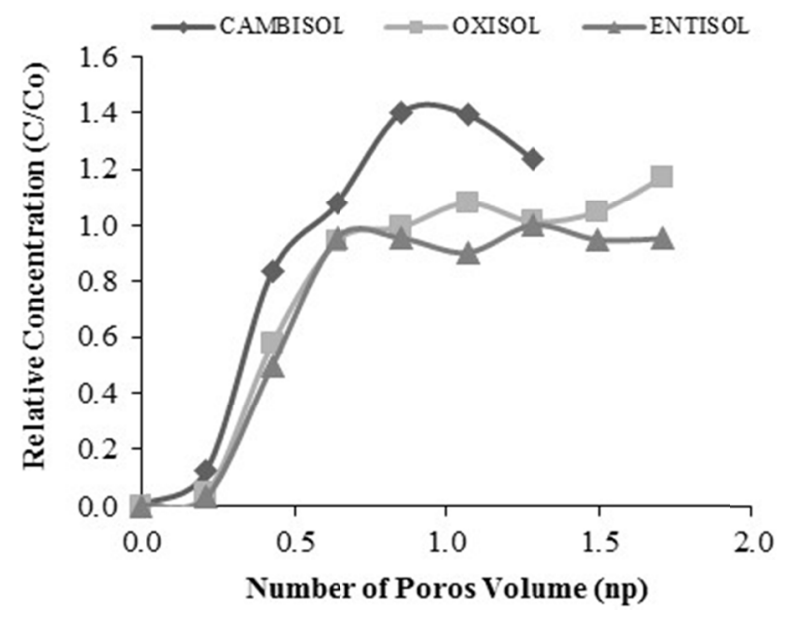

Figure 2. Calcium curve for each soil studied

As can be observed, for the $\mathrm{Ca}^{2+}$ ion, the retardation factor (R) was statistically equal for all soils, demonstrating that the slope point is almost equal, i.e., their retention powers were similar for this ion (Table 6). On the other hand, the dispersion-diffusion coefficient was statistically different for all soils, which means that, in each soil, the displacement of $\mathrm{Ca}$ is variable, being higher in soils with higher percentage of macropores: Latosol > Neosol > Cambisol (Table 5). With lower values of dispersion-diffusion coefficient (D) for the $\mathrm{Ca}^{2+}$ ion, the Cambisol showed higher contamination power; consequently, the Latosol showed lower contamination power by 
this ion (Table 5). In an experimental and numerical study on $\mathrm{Ca}^{2+}$ behavior in soil of the municipal landfill of Volta Redonda, Souza (2010) concluded that the higher the $\mathrm{Ca}^{2+}$ concentration in the contaminating solution, the more it is adsorbed by the soil. This result corroborates with that observed in the present study because, even with the high initial content of $\mathrm{Ca}^{2+}$ observed in the Cambisol (Table 3), the presence of a large number of negative charges allows this soil to continue avid for $\mathrm{Ca}^{2+}$ ions, and it can be easily salinized compared with the other studied soils.

Table 5. Calcium ion parameters in each soil subjected to Tukey test at 0.05 probability level

\begin{tabular}{lll}
\hline Soil & $\mathrm{R}$ & $\mathrm{D}\left(\mathrm{cm}^{2} \mathrm{~h}^{-1}\right)$ \\
\hline Eutrophic CAMBISOL & $0.33 \mathrm{a}$ & $25.07 \mathrm{a}$ \\
Typic Dystrophic Red OXISOL & $0.40 \mathrm{a}$ & $550.61 \mathrm{~b}$ \\
Entisol Quartzipsamment & $0.42 \mathrm{a}$ & $109.22 \mathrm{c}$ \\
\hline
\end{tabular}

Table 6. Magnesium ion parameters in each soil subjected to Tukey test at 0.05 probability level

\begin{tabular}{lll}
\hline Soil & $\mathrm{R}$ & $\mathrm{D}\left(\mathrm{cm}^{2} \mathrm{~h}^{-1}\right)$ \\
\hline Eutrophic CAMBISOL & $0.46 \mathrm{a}$ & $63.71 \mathrm{a}$ \\
Typic Dystrophic Red OXISOL & $0.51 \mathrm{~b}$ & $403.09 \mathrm{~b}$ \\
Entisol Quartzipsamment & $0.40 \mathrm{c}$ & $148.66 \mathrm{c}$ \\
\hline
\end{tabular}

For $\mathrm{Mg}^{2+}$, the sigmoid curve was similar for Latosol, Cambisol and Quartzarenic Neosol. In addition, there was small oscillation in the points of stability of the curve (Figure 3). However, it is noted that the Quartzarenic Neosol has the highest peaks of the $\mathrm{Mg}^{2+}$ ion, close to the maximum level of relative concentration $(\mathrm{C} / \mathrm{Co}=1)$. This behavior can be explained by the low number of negative charges present in these soils, due to their predominant composition of quartz, and their large number of macropores resulting from the loose structure (Santos et al., 2013), allowing $\mathrm{Mg}^{2+}$ ions to move more easily compared with the other soils, due to its lower retardation factor (Table 6). Santos et al. (2010b) found that the adsorption effect of the $\mathrm{Mg}^{2+}$ ion in Regolithic Neosol can be observed through its effluent distribution curve, which reflects its highest retardation factor, compared with $\mathrm{Ca}$, $\mathrm{Na}$ and $\mathrm{K}$.

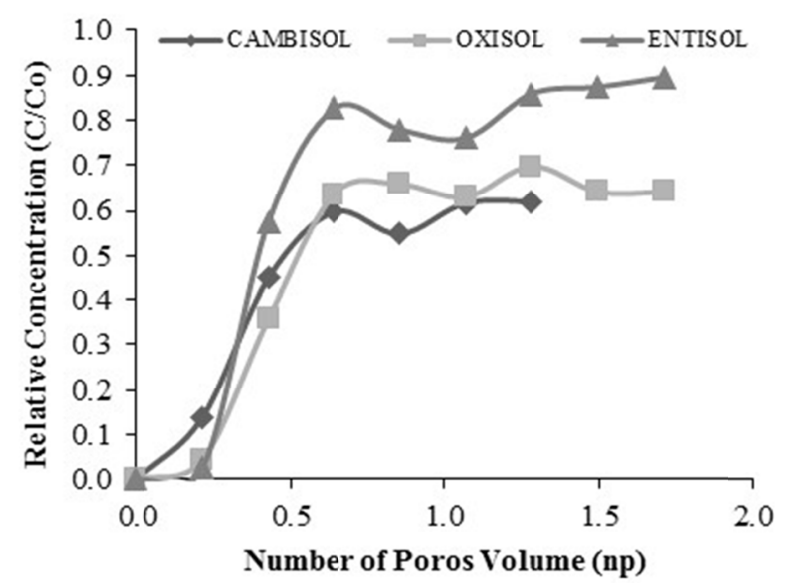

Figure 3. Magnesium curve for each soil studied

As can be observed, for the $\mathrm{Mg}$ ion, the retardation factor was statistically different for the soils, demonstrating that the slope point is different for the soils. The dispersion-diffusion coefficient was also statistically different for the soils, which means that, in each soil, the displacement of $\mathrm{Mg}^{2+}$ is variable, being higher in the Latosol (Table 6). The $\mathrm{D}$ values for the $\mathrm{Mg}$ ion, regarding its contamination power, are higher in the Cambisol and lower in the Latosol. Since the R values are statistically different for the studied soils, retention powers of the soils are different for this ion. However, as presented in the study of Ferreira (2006), who worked with conilon coffee 
wastewater, the retardation factor and dispersion-diffusion coefficient for the ions $\mathrm{K}^{+}, \mathrm{Na}^{+}, \mathrm{Ca}^{2+}$ and $\mathrm{Mg}^{2+}$ were lower than those of the present study.

For electrical conductivity, the same behavior of chloride was evident in the studied soils (Figure 4). Regarding the chemical characteristics of the studied soils, it is possible to note the reason for each behavior. Since the CEC of the Cambisol was higher compared with the others, this soil has greater potential of ion retention, thus showing higher chances of contamination by the saline waste used. However, as evidenced, for each ion, the Neosol exhibited higher advance speed of $\mathrm{K}^{+}$and $\mathrm{Cl}^{-}(\mathrm{R})$, i.e., higher contamination power. Melo (2006), through resident concentration curves, found that the ions advanced more in the column of sandy-textured soil, in comparison to those of medium and clay texture, whose retardation factors are, in general, higher.

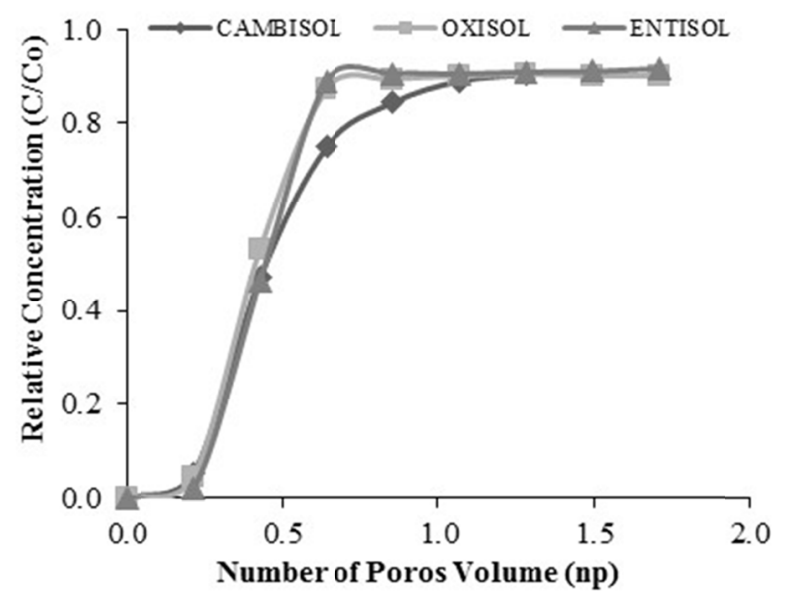

Figure 4. Electrical conductivity curve for each soil studied

Monitoring the mobilization of $\mathrm{Na}^{+}, \mathrm{K}^{+}$and $\mathrm{Cl}^{-}$ions in the same soils studied in the present research, Oliveira et al. (2016) observed that there was difference in their displacement between the types of soils. These authors observed that $\mathrm{K}^{+}$and $\mathrm{Cl}^{-}$ions exhibited higher advance speed in the Neosol, which showed highest risk of contamination in surface, corroborating the displacement of $\mathrm{Mg}^{2+}$ ions observed in the present study (Figure 2). In the Latosol, all ions $\left(\mathrm{Na}^{+}, \mathrm{K}^{+}\right.$and $\left.\mathrm{Cl}^{-}\right)$move more easily, a fact also observed for $\mathrm{Ca}^{2+}$ and $\mathrm{Mg}^{2+}$ ions in the present study (Figures 1 and 2). Hence, the application of saline waste in this soil leads to great possibilities of water table contamination. For the Cambisol, the small displacement of $\mathrm{Ca}^{2+}$ and $\mathrm{Mg}^{2+}$ ions, in the present study, has also been observed by the authors for the ions $\mathrm{Na}^{+}, \mathrm{K}^{+}$and $\mathrm{Cl}^{-}$, denoting that this soil has high buffering power and, consequently, higher risk of salinization compared with the others.

\section{Conclusions}

In the Red Oxisol, $\mathrm{Ca}^{2+}$ and $\mathrm{Mg}^{2+}$ ions move with greater ease resulting in possibility largest of potential of ground water contamination.

In Entisol Quartzipsamment presented higher $\mathrm{Mg}^{2+}(\mathrm{R})$ ion advancement speed, that is, higher subsurface contamination power for these ions.

The eutrophic Cambisol presented low diffusion-dispersion coefficient in all the evaluated ions and, therefore, lower mobility of the ions in the soil profile, and consequently, a greater possibility of contamination when irrigated with reject brine.

\section{References}

Anami, M. H., Sampaio, S. C., Suszek, M., Gomes, S. D., \& Queiroz, M. M. F. (2008). Deslocamento miscível de nitrato e fosfato proveniente de água residuária da suinocultura em colunas de solo. Rev. Bras. de Eng. Agri. e Ambi., 12, 75-80. https://doi.org/10.1590/S1415-43662008000100011

Ayers, R. S., \& Westcot, D. W. (1999). In H. R. Gheyi, J. F. Medeiros, \& F. A. V. Damasceno (Trans.), $A$ qualidade da água na agricultura (2st ed., p. 153). Campina Grande: Universidade Federal da Paraíba. 
Borges Junior, J. C. F., \& Ferreira, P. A. (2006). Equações e programa computacional para cálculo do transporte de solutos no solo. Rev. Bras. de Eng. Agri. e Ambi., 10, 604-611. https://doi.org/10.1590/S1415-43662006000 300010

Cosme, C. R., Dias, N. S., Oliveira, A. M., Oliveira, E. M. M., \& Sousa Neto, O. N. (2011). Produção de tomate hidropônico utilizando rejeito da dessalinização na solução nutritiva aplicados em diferentes épocas. Rev. Bras. de Eng. Agri. e Ambi., 15, 499-504. https://doi.org/10.1590/S1415-43662011000500010

Dias, N. S., Lira, R. B., Brito, R. F., Sousa Neto, O. N., Ferreira Neto, M., \& Oliveira, A. M. (2010). Produção de melão rendilhado em sistema hidropônico com rejeito da dessalinização de água em solução nutritiva. Rev. Bras. de Eng. Agri. e Ambi., 14, 755-761. https://doi.org/10.1590/S1415-43662010000700011

Embrapa (Empresa Brasileira de Pesquisa Agropecuária). (1997). Manual de métodos de análise de solo (2nd ed., p. 212). Rio de Janeiro: Embrapa.

Ferreira, D. F. (2011). Sisvar: A computer statistical analysis system. Cien. \& Agrotec., 35, $1039-1042$. https://doi.org/10.1590/S1413-70542011000600001

Ferreira, P. A., Garcia, G. O., Matos, A. T., Ruiz, H. A., \& Borges Junior, J. C. F. (2006). Transporte no solo de solutos presentes na água residuária de café conilon. Acta Scient. Agronomy, 28, 29-35. https://doi.org/ 10.4025/actasciagron.v28i1.1295

Garcia, G. O., Martins Filho, S., Reis, E. F., Moraes, W. B., \& Nazário, A. A. (2008). Alterações químicas de dois solos irrigados com água salina. Rev. Cien. Agronômica, 39, 7-18.

Matos, A. T., Gariglio, H. A. A., \& Lo Monaco, P. A. V. (2013). Deslocamento miscível de cátions provenientes da vinhaça em colunas de solo. Rev. Bras. de Eng. Agri. e Ambi., 17, 743-749. https://doi.org/10.1590/ S1415-43662013000700008

Melo, R. F. M., Ferreira, P. A., Matos, A. T., Ruiz, H. A., \& Oliveira, L. B. (2006). Deslocamento miscível de cátions básicos provenientes da água residuária de mandioca em colunas de solo. Rev. Bras. de Eng. Agri. e Ambi., 10, 456-465. https://doi.org/10.1590/S1415-43662006000200029

Mesquita, E. F., Sá, F. V. S., Bertino, A. M. P., Cavalcante, L. F., Paiva, E. P., \& Ferreira, N. M. (2015). Effect of soil conditioners on the chemical attributes of a saline-sodic soil and on the initial growth of the castor bean plant. Semina: Cien. Agrárias, 36, 2527-2538. https://doi.org/10.5433/1679-0359.2015v36n4p2527

Miranda, M. A., Oliveira, E. E. M., Santos, K. C. F., Freire, M. B. G. S., \& Almeida, B. G. (2011). Condicionadores químicos e orgânicos na recuperação de solo salino-sódico em casa de vegetação. Rev. Bras. de Eng. Agri. e Ambi., 15, 484-490. https://doi.org/10.1590/S1415-43662011000500008

Oliveira, A. M. P., Rebouças, C. A. M., Dias, N. S., Portela, J. C., \& Diniz, A. A. (2016). Contamination potential of specific ions in soil treated with reject brine from desalination plants. Rev. Caatinga, 29, 569-577. https://doi.org/10.1590/1983-21252016v29n306rc

Pinho, R. E. C., \& Miranda, J. H. (2014). Avaliação do modelo HYDRUS-1D na simulação do transporte de água e potássio em colunas preenchidas com solos tropicais. Eng. Agrícola, 34, 899-911. https://doi.org/ 10.1590/S0100-69162014000500009

Sá, F. V. S., Mesquita, E. F., Bertino, A. M. P., Costa, J. D., \& Araújo, J. L. (2015). Influência do gesso e biofertilizante nos atributos químicos de um solo salino-sódico e no crescimento inicial do girassol. Irriga, 20, 46-59. https://doi.org/10.15809/irriga.2015v20n1p46

Santos, A. N., Silva, E. F. F., Soares, T. M., Dantas, R. M. L., \& Silva, M. M. (2011). Produção de alface em NFT e Floating aproveitando água salobra e o rejeito da dessalinização. Rev. Cien. Agronômica, 2, 319-326. https://doi.org/10.1590/S1806-66902011000200009

Santos, A. N., Soares, T. S., Silva, E. F. F., Silva, D. J. R., \& Montenegro, A. A. A. (2010a). Cultivo hidropônico de alface com água salobra subterrânea e rejeito da dessalinização em Ibimirim, PE. Rev. Bras. de Eng. Agri. e Ambi., 14, 961-969. https://doi.org/10.1590/S1415-43662010000900008

Santos, H. G., Jacomine, P. K. T., Anjos, L. H. C., Oliveira, V. A., Oliveira, J. B., Coelho, M. R., ... Cunha, T. J. F. (2013). Sistema Brasileiro de Classificação de Solos (3st ed., p. 306). Brasília: Embrapa Informação Tecnológica.

Santos, J. S., Lima, V. L. A., Borges Júnior, J. C. F., Leda, V. B. D., Silva, L. V. B. D., \& Azevedo, C. A. V. (2010b). Mobilidade de solutos em colunas de solo com água residuária doméstica e de suinocultura. Rev. Bras. de Eng. Agri. e Ambi., 14, 1226-1233. https://doi.org/10.1590/S1415-43662010001100013 
Silva, L. P., Quirijn, J. V. L., Correa, M. M., Miranda, J. H., \& Oliveira, L. A. (2016). Retention and solute transport properties in disturbed and undisturbed soil samples. Rev. Bras. de Cien. do Solo, 40, 1-10. https://doi.org/10.1590/18069657rbcs20151045

Silva, M. A. S., Griebeler, N. P., \& Borges, L. C. (2007). Uso de vinhaça e impactos nas propriedades do solo e lençol freático. Rev. Bras. de Eng. Agri. e Ambi., 11, 108-114. https://doi.org/10.1590/S1415-4366200700 0100014

Silva, N. F., Lelis Neto, J. A., Teixeira, M. B., Cunha, F. N., Miranda, J. H., \& Coelho, R. D. (2012). Distribuição de solutos em colunas de solo com vinhaça. Irriga, 1(Special), 340-350. https://doi.org/10.15809/ irriga.2012v1n01p340

Tedesco, M. J., Gianello, C., Bissani, C. A., Bohnen, H., \& Volkweiss, S. J. (1995). Análise de solo, plantas e outros materiais (2st ed., p. 174). Porto Alegre: UFRGS.

\section{Copyrights}

Copyright for this article is retained by the author(s), with first publication rights granted to the journal.

This is an open-access article distributed under the terms and conditions of the Creative Commons Attribution license (http://creativecommons.org/licenses/by/4.0/). 